\title{
Will Worldwide Adoption Of IFRS Improve Comparability? An Instructional Case Between Two Companies In Two Countries
}

Kris Portz, St. Cloud State University, USA Joel Strong, St. Cloud State University, USA

\begin{abstract}
One of the most compelling arguments for US companies to adopt IFRS is to increase comparability between companies and countries worldwide. This instructional case emphasizes to students that even though two companies both follow the same set of accounting rules (IFRS in this case), comparability of financial statements can still be difficult due to accounting choices, judgments, and estimates made by management. In this case, two start-up companies enter the renewable energy industry and begin retailing wind turbines. Students record identical first-year transactions for the two companies, record six additional transactions where each company makes different accounting choices when applying IFRS, prepare a set of financial statements, and calculate ratios. Through these tasks, students can see how accounting choices made by management affect comparability of the financial statements. This case also gives students an opportunity to discuss how culture and the general accounting environment in a country may influence the accounting choices made by management.
\end{abstract}

Keywords: International Financial Reporting Standards (IFRS); Comparability; Ratios; Culture; Worldwide Accounting Practices; Accounting Cycle

\section{THE CASE}

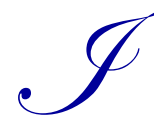

n January 2014, two companies enter the renewable energy industry and begin retailing wind turbines for home or commercial use. The corporate mission of both companies is to make wind energy available to the mainstream. Munich Windet, Co. is located in Munich, Germany and AmsterWind, Inc. is located in Amsterdam, Netherlands. The companies operate under similar economic conditions and have identical operations during the first year. However, each company makes different accounting decisions when applying IFRS to six additional transactions. IFRS is required for financial reporting by all public companies operating within the European Union and has been since 2005.

\section{Requirement 1 - Record the First Year Transactions for 2014}

Both companies have identical operations during the year 2014. The first year transactions for both companies are as follows:

1. On January 1, each company issues 5,000 shares of no-par, capital stock for $€ 500,000$ and began operations.

2. On January 2, each company borrowed $€ 300,000$ on a 10 -year, $5 \%$ note payable. Interest plus $€ 30,000$ principal is due September 30 each year, beginning 2014.

3. On January 3, each company purchased land and a building for $€ 350,000$ in cash. Based on appraisals, both companies assigned $€ 50,000$ to the land and $€ 300,000$ to the building. 
4. On January 5, each company purchased equipment, with cash, at a cost of $€ 40,000$.

5. Each company sells one type of wind turbine and made the following inventory purchases on credit during the year (see Table 1). Record all purchases as one transaction.

Table 1: Inventory Purchases on Credit During the Year 2014

\begin{tabular}{|l|c|c|}
\hline \multicolumn{3}{|c|}{ Inventory Purchased } \\
\hline Date & Units & Cost per Unit \\
\hline February 2 & 30 & $€ 1,200$ \\
\hline March 15 & 50 & $€ 1,250$ \\
\hline August 3 & 75 & $€ 1,300$ \\
\hline October 20 & 40 & $€ 1,350$ \\
\hline December 1 & 60 & $€ 1,400$ \\
\hline
\end{tabular}

6. Each company sold 180 units for $€ 2,500$ each, totaling sales of $€ 450,000$ for the year, all on credit. Management uses the periodic inventory system and will record cost of goods sold at the end of the year. For now, record only the sales revenue.

7. Cash collected during the year from credit sales from transaction 6 totaled $€ 360,000$.

8. Cash paid for inventory purchases from transaction 5 was $€ 280,000$.

9. The first payment of principal of $€ 30,000$ and nine months of accrued interest is made on September 30 for the note payable from transaction 2.

10. Cash of $€ 60,000$ was paid for other operating expenses. While these expenses include a variety of expenses such as salaries, insurance, and start-up costs, record the $€ 60,000$ as one transaction to "Other Operating Expenses."

11. On December 10, dividends of $€ 5.00$ per share were declared and paid to stockholders.

12. Record an adjusting entry to accrue three months of interest on the note payable in transaction 2 . Remember one principal and interest payment was already made on September 30 (transaction 9).

Requirement 1: Record these transactions for Munich Windet, Co. and AmsterWind, Inc. for the first year of operations. Only one set of journal entries is necessary because they are the same for both companies. Use the chart of account below (Table 2) to record the journal entries in requirement one and two.

Table 2: Chart of Accounts

\begin{tabular}{|l|l|l|}
\hline \multicolumn{2}{|c|}{ Chart of Accounts } \\
\hline \multicolumn{1}{|c|}{ Asset Accounts } & \multicolumn{1}{c|}{ Liability Accounts } & \multicolumn{1}{c|}{ Equity Accounts } \\
\hline Cash & Accounts Payable & Called Up Share Capital \\
Accounts Receivable & Interest Payable & Retained Earnings \\
Allowance for Doubtful Accounts & Note Payable & Dividends \\
Inventory & Finance Lease Liability & Sales \\
Land & Provision for Litigation Loss & Cost of Goods Sold \\
Buildings & & Bad Debt Expense \\
Accumulated Depreciation - Building & & Depreciation Expense \\
Equipment & & Interest Expense \\
Accumulated Depreciation - Equipment & & Other Operating Expenses \\
Leased Equipment & & Rent Expense \\
Accumulated Depreciation- Leased & & Litigation Loss \\
Equipment & Provision for Income Tax \\
\hline
\end{tabular}

\section{Requirement 2 - Accounting Choices, Judgments, and Estimates}

On December 31, 2014, Munich Windet and AmsterWind make different accounting decisions in recording the following transactions.

1. Property, Plant, and Equipment

a. Munich Windet estimates the useful lives and salvage value of the building and equipment owned by the company as follows: 


\begin{tabular}{|c|c|c|c|}
\hline & & $\underline{\text { Useful Lives }}$ & $\underline{\text { Salvage Value }}$ \\
\hline Buildit & $€ 300,000$ & 25 years & $€ 50,000$ \\
\hline Equipment & $€ 40,000$ & 4 years & $€ 4,000$ \\
\hline
\end{tabular}

Munich Windet uses straight-line depreciation for both the building and equipment.

b. AmsterWind estimates the useful lives and salvage value of the building and equipment owned by the company as follows:

\begin{tabular}{|c|c|c|c|}
\hline & & $\underline{\text { Useful Lives }}$ & $\underline{\text { Salvage Value }}$ \\
\hline Bui & $€ 300,000$ & 30 years & $€ 40,000$ \\
\hline Equipment & $€ 40,000$ & 8 years & $€ 2,000$ \\
\hline
\end{tabular}

AmsterWind uses straight-line depreciation for both the building and equipment. At December 31, AmsterWind also elects to revalue the building to fair market value as allowed by IAS 16 - Property, Plant, and Equipment. AmsterWind obtained an appraisal on the building and the fair value of the building is estimated to be $€ 330,000$. To record the revaluation, AmsterWind elects to eliminate the accumulated depreciation against the building account and then increase the building account to the revalued amount of the asset. The increase in fair value is credited to the Revaluation Surplus account (an equity account). ${ }^{1}$

\section{Bad Debt Expense}

Both companies use the allowance method to account for bad debts. The managers at Munich Windet and AmsterWind make the following estimates based on an aging of their accounts receivable:

Munich Windet: $5 \%$ of the ending accounts receivable will be uncollectible AmsterWind: $1 \%$ of the ending accounting receivable will be uncollectible

\section{Inventory Costing}

A periodic inventory system is used so cost of goods sold was not recorded at the time of the sale. A physical count is done at year end and used to determine the values of cost of goods sold and ending inventory. 75 wind turbines remain in ending inventory. The managers opt to use the following inventory costing methods, both acceptable methods under IAS $2^{2}$ :

Munich Windet: Weighted Average

AmsterWind: FIFO (First-In-First-Out)

\section{Equipment Lease}

On January 2, 2014, both companies enter into a lease agreement for equipment. The terms of the lease are as follows. The lessee will pay $€ 10,000$ at the end of the year for the next seven years, at which time the equipment will have zero salvage value. The equipment has an economic life of 10 years. The title of the equipment remains with the lessor at the end of the lease, and there is no bargain purchase option. Both companies incremental borrowing rate is $10 \%$. The implicit rate is unknown. Both the cost and the fair value of the equipment is $€ 62,500$.

Under IFRS, there are no bright line tests for leases. The IFRS criteria for recording a finance lease according to IAS 17 are:

1. Ownership transfers to lessee at the end of the lease.

2. Option to purchase the asset at a price less than fair value at the end of the lease term.

\footnotetext{
${ }^{1}$ IAS 16 allows for two alternative treatments in recording the revaluation. The other alternative is to restate the accumulated depreciation proportionally with the change in the gross carrying amount of the asset so that the carrying amount of the asset after revaluation equals its revalued amount.

${ }^{2}$ IAS 2 prohibits LIFO.
} 
3. The lease term is for the major part of useful life.

4. The present value of minimum lease payments at the inception of the lease is equal to substantially all the fair value of the leased asset.

5. The leased asset is of a specialized nature such that only the lessee can use it without major modifications. ${ }^{3}$

Munich Windet: The company judges that the lease term is not a major part of the useful life $(7 / 10=70 \%)$ and the present value of the minimum lease payments are not substantially all of the fair value of the leased asset $(€ 48,684 / € 62,500=78 \%)$. The other criteria are not met. Therefore, Munich Windet classifies this as an operating lease and records the annual lease payment of $€ 10,000$ as rent expense.

AmsterWind: The company judges the lease term is a major part of the useful life $(7 / 10=70 \%)$ and the present value of the minimum lease payments is substantially all of the fair value of the leased asset $(€ 48,684 / € 62,500=78 \%)$. The other criteria are not met. Therefore, AmsterWind classifies this as a finance lease. The first two payments are to be allocated to interest and principal as follows:

$\begin{array}{lll} & \underline{\text { Interest }} & \text { Principal } \\ \text { December 31, 2014 } & € 4,868 & € 5,132 \\ \text { December 31, 2015 } & € 4,355 & € 5,645\end{array}$

AmsterWind takes a full year of depreciation in the first year of the lease and computes depreciation using straight-line depreciation with a life equal to the seven-year lease term with no salvage value.

\section{Provision}

Both companies face potential damages related to an intellectual property lawsuit filed against them. Company attorneys evaluate the case and estimate that potential losses range from $€ 40,000$ to $€ 60,000^{4}$. IAS 37 distinguishes between a provision, which is accrued on the balance sheet and a contingent liability, which is not. Provisions are recognized when the loss is probable (defined as more likely than not) and a reliable estimate of the obligation can be made. With a $60 \%$ chance of losing the lawsuit, Munich Windet judges the lawsuit to be probable (more likely than not) and therefore, accrues for the provision. AmsterWind judges the lawsuit to be reasonably possible and chooses to disclose the contingent liability in their footnotes, rather than accrue for the loss.

\section{6. $\quad$ Provision for Income Tax}

Both companies must make an estimated tax payment to their respective governments by year end. Thus, each manager records a provision for income tax and a cash payment on December 31. This is not an accrual; cash was paid for income taxes at this time.

Munich Windet: tax rate is $25 \%$ of IFRS income

AmsterWind: tax rate is $25 \%$ of IFRS income

Requirement 2: Record the last six transactions for Munich Windet and AmsterWind and prepare an income statement, statement of retained earnings, statement of financial position, and statement of cash flows (direct method) for both Munich Windet and AmsterWind for the year ended December 31, 2014.

\section{Requirement 3 - Calculate Ratios}

Requirement 3: Analyze the financial statements of the two companies by calculating liquidity, profitability, and long-term solvency ratios. Include the ratios listed in the table below (Table 3). For any ratios that

\footnotetext{
${ }^{3}$ IAS 17 provides three additional indicators of situations that individually or in combination could lead to a lease being classified as a finance lease: the lessee bears the lessor's losses if the lessee cancels the lease, the lessee absorbs the gains or losses from fluctuations in the fair value of the residual value of the asset, or the lessee may extend the lease for a secondary period at a rent substantially below the market rent.

${ }^{4}$ If the company has a range for the loss, IAS 37 requires companies to accrue for the mid-point of the range.
} 
require average account balances (i.e., average total assets), use the year-end balances, since the beginning balances are all zero. See Appendix 1 for the ratio formulas.

Table 3: Liquidity, Profitability, and Long-Term Solvency Ratios

\begin{tabular}{|c|c|c|}
\hline \multicolumn{3}{|c|}{ Financial Ratios } \\
\hline Liquidity Ratios & Profitability Ratios & Long-Term Solvency Ratios \\
\hline $\begin{array}{l}\text { Current ratio } \\
\text { Acid-test ratio } \\
\text { Accounts receivable turnover } \\
\text { Days to collect receivables } \\
\text { Inventory turnover } \\
\text { Days to sell inventory } \\
\text { Operating Cycle }\end{array}$ & $\begin{array}{l}\text { Gross Profit Margin } \\
\text { Profit Margin } \\
\text { Return on assets (ROA) } \\
\text { Return on owners' equity (ROE) } \\
\text { Earnings per share (EPS) }\end{array}$ & $\begin{array}{l}\text { Debt ratio } \\
\text { Times interest earned }\end{array}$ \\
\hline
\end{tabular}

\section{TEACHING NOTES}

\section{Learning Objectives}

The primary learning objective of this case is to help students appreciate that there will always be challenges with comparability even if two companies prepare their financial statements using the same set of accounting rules, IFRS in this case. One of the most common and compelling arguments for US companies to adopt IFRS is to increase comparability on a global level. Proponents of international convergence argue that comparability of financial statements worldwide is necessary for the globalization of capital markets. While crosscountry comparability ideally would improve if all countries adopted IFRS, there will always be limitations in comparability due to accounting choices, judgment, and estimates when applying IFRS. Through recording several journal entries and preparing financial statements for two companies, students can see how accounting decisions and the application of IFRS directly impact comparability. Other learning objectives of this case are to give students an opportunity to discuss how accounting decisions can be influenced by a country's culture and the general accounting environment within a country. Students should also be able to see the difference between operational differences and accounting differences in the appearance of the financial strength or weakness of a company.

The requirements of this case are divided into three parts. Students start by recording the first year of transactions for Munich Windet Co. and AmsterWind, Inc. These transactions are identical for both companies. After recording the first year transactions, students then record six additional transactions and prepare a set of IFRS financial statements. In these six transactions, the companies make different accounting decisions in the measurement and recognition of fixed assets, accounts receivable, inventory, an equipment lease, and a potential liability. The different accounting decisions result in differences in profitability, financial position, and cash flows. Finally, students calculate and compare financial ratios.

\section{Implementation Guidance}

This case is appropriate for an intermediate accounting course, an international accounting course, or a financial statement analysis course, at either the undergraduate or graduate level. One way to assign this case is to divide the three requirements between three class periods. Assign each requirement as homework and discuss the solution in the next class. This allows students to make sure they have the correct solutions before moving to the next requirement. Another option would be to cover the case in one class period. Students can complete the case, individually or in groups, as homework or during class time. This case could also be effective in an online environment with questions posted to an online discussion board.

Other possible ways to use this case would be use it as a way to highlight some of the differences between US GAAP and IFRS. The IFRS/US GAAP differences in this case include the option to revalue property, plant, and equipment, the no LIFO option for inventory costing, the criteria for recognizing financial leases, and accounting for provisions. References to the applicable IAS have been made throughout the case. This case could also be used for a financial statement analysis discussion by giving students a copy of the financial statements and ratios and discuss with them how differences in accounting decisions, culture and the accounting environment can explain some of the 
differences seen in the performance results and ratios of the two companies. Finally, this case could simply be used for practice and review of the accounting cycle.

\section{Solutions to the Case}

The first requirement is to record the journal entries for the first year of operations. These transactions are the same for both Munich Windet and AmsterWind (see Table 4).

Table 4: Journal Entries for the First Year of Operations

\begin{tabular}{|c|c|c|c|}
\hline \multicolumn{4}{|c|}{ Solution to Requirement 1: Journal Entries for the First Year } \\
\hline \multirow[t]{2}{*}{1} & Cash & 500,000 & \\
\hline & Called Up Share Capital & & 500,000 \\
\hline \multirow[t]{2}{*}{2} & Cash & 300,000 & \\
\hline & Note Payable & & 300,000 \\
\hline \multirow[t]{3}{*}{3} & Land & 50,000 & \\
\hline & Building & 300,000 & \\
\hline & Cash & & 350,000 \\
\hline \multirow[t]{2}{*}{4} & Equipment & 40,000 & \\
\hline & Cash & & 40,000 \\
\hline \multirow[t]{2}{*}{5} & Inventory & 334,000 & \\
\hline & Accounts Payable & & 334,000 \\
\hline \multirow[t]{2}{*}{6} & Accounts Receivable & 450,000 & \\
\hline & Sales Revenue & & 450,000 \\
\hline \multirow[t]{2}{*}{7} & Cash & 360,000 & \\
\hline & Accounts Receivable & & 360,000 \\
\hline \multirow[t]{2}{*}{8} & Accounts Payable & 280,000 & \\
\hline & Cash & & 280,000 \\
\hline \multirow[t]{3}{*}{9} & Note Payable & 30,000 & \\
\hline & Interest Expense $(300,000 * .05 * 9 / 12)$ & 11,250 & \\
\hline & Cash & & 41,250 \\
\hline \multirow[t]{2}{*}{10} & Other Operating Expenses & 60,000 & \\
\hline & Cash & & 60,000 \\
\hline \multirow[t]{2}{*}{11} & Dividends & 25,000 & \\
\hline & Cash & & 25,000 \\
\hline \multirow[t]{3}{*}{12} & Interest Expense & 3,375 & \\
\hline & Interest Payable & & 3,375 \\
\hline & $(300,000-30,000) * .05 * 3 / 12$ & & \\
\hline
\end{tabular}

The second requirement is to record the journal entries for the six additional transactions and prepare a set of financial statements for Munich Windet and AmsterWind (see Table 5 and Table 6). 
Table 5: Solution to Requirement 2 - Journal Entries for Additional Transactions for Munich Windet

\begin{tabular}{|c|c|c|c|}
\hline \multicolumn{4}{|c|}{ Solutions for Munich Windet } \\
\hline 1 & Depreciation Expense - Building & 10,000 & \\
\hline & Accumulated Depreciation - Building & & 10,000 \\
\hline & $(300,000-50,000) / 25$ & & \\
\hline & Depreciation Expense - Equipment & 9,000 & \\
\hline & Accumulated Depreciation -Equipment & & 9,000 \\
\hline & $(40,000-4,000) / 4$ & & \\
\hline 2 & Bad Debt Expense & 4,500 & \\
\hline & Allowance for Doubtful Accounts & & 4,500 \\
\hline & $90,000^{*} .05$ & & \\
\hline 3 & Cost of Goods Sold & 235,800 & \\
\hline & Inventory & & 235,800 \\
\hline & $(€ 334,000 / 255)=€ 1,310 * 180$ & & \\
\hline 4 & Rent Expense & 10,000 & \\
\hline & Cash & & 10,000 \\
\hline 5 & Litigation Loss & 50,000 & \\
\hline & Provision for Litigation Loss & & 50,000 \\
\hline 6 & Provision for Income Tax & 14,019 & \\
\hline & Cash & & 14,019 \\
\hline & $€ 56,075 * 25 \%$ & & \\
\hline
\end{tabular}

Table 6: Solution to Requirement 2 - Journal Entries for Additional Transactions for AmsterWind

\begin{tabular}{|c|c|c|c|}
\hline \multicolumn{4}{|c|}{ Solutions for AmsterWind } \\
\hline 1 & Depreciation Expense - Building & 8,667 & \\
\hline & Accumulated Depreciation - Building & & 8,667 \\
\hline & $(300,000-40,000) 30$ & & \\
\hline & Depreciation Expense - Equipment & 4.750 & \\
\hline & Accumulated Depreciation -Equipment & & 4,750 \\
\hline & $(40,000-2,000) / 8$ & & \\
\hline & Accumulated Depreciation -Building & 8.667 & \\
\hline & Building & & 8,667 \\
\hline & Building & 38,667 & \\
\hline & Revaluation Surplus & & 38,667 \\
\hline 2 & Bad Debt Expense & 900 & \\
\hline & Allowance for Doubtful Accounts & & 900 \\
\hline & $90,000 * .01$ & & \\
\hline 3 & Cost of Goods Sold & 229,750 & \\
\hline & Inventory & & 229,750 \\
\hline & $(30 * \epsilon 1,200)+(50 * \epsilon 1,250)+(75 * \epsilon 1,300)+(25 * \epsilon 1,350)$ & & \\
\hline 4 & Leased Equipment & 48,684 & \\
\hline & Finance Lease Liability & & 48,684 \\
\hline & Interest Expense & 4,868 & \\
\hline & Finance Lease Liability & 5,132 & \\
\hline & Cash & & 10,000 \\
\hline & Depreciation Expense- Leased Equipment & 6,955 & \\
\hline & Accumulated Depreciation & & 6,955 \\
\hline & $(€ 48,684-0) / 7$ & & \\
\hline
\end{tabular}


Table 6 cont.

\begin{tabular}{|l|l|l|l|}
\hline 5 & No accrual for Provision; disclosure only & & \\
\hline & & & \\
\hline 6 & Provision for Income Tax & 29,871 & \\
\hline & Cash & & 29,871 \\
\hline & $€ 119,485 * 25 \%$ & & \\
\hline
\end{tabular}

The financial statements for Munich Windet and AmsterWind for the year ended December 31, 2014 are below (see Tables 7 - 10). The statements are shown side by side for easier comparison of the two companies.

Table 7: Statement of Earnings for the Year Ended December 31, 2014

\begin{tabular}{|c|c|c|c|c|}
\hline & Munich Windet & & AmsterWind & \\
\hline Sales Revenue & $€ 450,000$ & & $€ 450,000$ & \\
\hline Cost of Goods Sold & $\underline{235,800}$ & $52.4 \%$ & $\underline{229,750}$ & $51.1 \%$ \\
\hline Gross Profit & 214,200 & $47.6 \%$ & 220,250 & $48.9 \%$ \\
\hline \multicolumn{5}{|l|}{ Less: } \\
\hline Other Operating Expenses & 60,000 & $13.3 \%$ & 60,000 & $13.3 \%$ \\
\hline Depreciation Expense & 19,000 & $4.2 \%$ & 20,372 & $4.5 \%$ \\
\hline Bad Debt Expense & 4,500 & $1.0 \%$ & 900 & $.2 \%$ \\
\hline Rent Expense & 10,000 & $2.2 \%$ & $\underline{0}$ & \\
\hline Income from Operations & 120,700 & $26.9 \%$ & 138,978 & $30.9 \%$ \\
\hline \multicolumn{5}{|l|}{ Other Expenses and Losses: } \\
\hline Litigation Loss & 50,000 & $11.1 \%$ & 0 & \\
\hline Interest Expense & 14,625 & $3.3 \%$ & 19,493 & $4.3 \%$ \\
\hline Income Before Tax & $\overline{56,075}$ & $12.5 \%$ & 119,485 & $26.6 \%$ \\
\hline Provision for Income Tax $(25 \%)$ & 14,019 & $3.1 \%$ & 29,871 & $6.6 \%$ \\
\hline Net Income & $€ \overline{\underline{\epsilon 2,056}}$ & $9.4 \%$ & $€ 89,614$ & $20.0 \%$ \\
\hline Earnings per Share (EPS) & $€ 8.41$ & & $€ 17.92$ & \\
\hline
\end{tabular}

Table 8: Statement of Retained Earnings for the Year Ended December 31, 2014

\begin{tabular}{|l|r|r|}
\hline & \multicolumn{1}{|c|}{ AmsterWind } \\
\hline Retained Earnings, January 1, 2014 & $€ 0$ & $€ 0$ \\
\hline Add: Net Income & 42,056 & 89,614 \\
\hline Less: Dividends & $\underline{(25,000)}$ & $\underline{(25,000)}$ \\
\hline Retained Earnings, December 31, 2014 & $\underline{\underline{€ 17,056}}$ & $\underline{\underline{€ 64,614}}$ \\
\hline
\end{tabular}


Table 9: Balance Sheet, December 31, 2014

\begin{tabular}{|c|c|c|}
\hline & Munich Windet & AmsterWind \\
\hline \multicolumn{3}{|l|}{ Noncurrent Assets } \\
\hline \multicolumn{3}{|l|}{ Property, Plant and Equipment: } \\
\hline Land & 50,000 & 50,000 \\
\hline Building & 300,000 & 330,000 \\
\hline $\mathrm{A} / \mathrm{D}-$ Building & $(10,000)$ & 0 \\
\hline Equipment & 40,000 & 40,000 \\
\hline A/D - Equipment & $(9,000)$ & $(4,750)$ \\
\hline Leased Equipment & 0 & 48,684 \\
\hline A/D - Leased Equipment & $\underline{\underline{0}}$ & $(6,955)$ \\
\hline Total Property, Plant and Equipment & 371,000 & 456,979 \\
\hline \multicolumn{3}{|l|}{ Current Assets: } \\
\hline Inventory & 98,200 & 104,250 \\
\hline Accounts Receivable & 90,000 & 90,000 \\
\hline Allowance for Doubtful Accounts & $(4,500)$ & $(900)$ \\
\hline Cash & 339,731 & $\underline{323,879}$ \\
\hline Total Current Assets & $\underline{523,431}$ & $\underline{517,229}$ \\
\hline Total Assets & $\underline{\mathbf{8 9 4 , 4 3 1}}$ & $\underline{974,208}$ \\
\hline \multicolumn{3}{|l|}{ Equity } \\
\hline Called Up Share Capital & 500,000 & 500,000 \\
\hline Revaluation Surplus & 0 & 38,667 \\
\hline Retained Earnings & 17,056 & 64,614 \\
\hline Total Equity & 517,056 & 603,281 \\
\hline \multicolumn{3}{|l|}{ Noncurrent Liabilities: } \\
\hline Note Payable & 240,000 & 240,000 \\
\hline Finance Lease Liability & 0 & 37,907 \\
\hline Provision for Litigation Loss & 50,000 & $\underline{0}$ \\
\hline Total Noncurrent Liabilities & 290,000 & 277,907 \\
\hline \multicolumn{3}{|l|}{ Current Liabilities: } \\
\hline Accounts Payable & 54,000 & 54,000 \\
\hline Interest Payable & 3,375 & 3,375 \\
\hline Current Portion of Note Payable & 30,000 & 30,000 \\
\hline Current Portion of Finance Lease & $\underline{0}$ & 5,645 \\
\hline Total Current Liabilities & $\underline{87,375}$ & 93,020 \\
\hline Total Liabilities & $\mathbf{3 7 7 , 3 7 5}$ & 370,927 \\
\hline Total Equity and Liabilities & 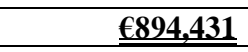 & $\underline{\underline{€ 94,208}}$ \\
\hline
\end{tabular}


Table 10: Statement of Cash Flows for the Year Ended December 31, 2014

\begin{tabular}{|c|c|c|}
\hline & Munich Windet & AmsterWind \\
\hline \multicolumn{3}{|l|}{ Cash Flows from Operating Activities: } \\
\hline Cash Received from Customers & 360,000 & 360,000 \\
\hline Cash Paid to Suppliers & $(280,000)$ & $(280,000)$ \\
\hline Cash Paid for Operating Expense & $(60,000)$ & $(60,000)$ \\
\hline Cash Paid for Interest & $(11,250)$ & $(16,118)$ \\
\hline Cash paid for Rent & $(10,000)$ & 0 \\
\hline Cash paid for Taxes & $(14,019)$ & $(29,871)$ \\
\hline Cash Inflow (Outflow) from Operating Activities & $(15,269)$ & $(25,989)$ \\
\hline \multicolumn{3}{|l|}{ Cash Flows from Investing Activities: } \\
\hline Purchase of Land & $(50,000)$ & $(50,000)$ \\
\hline Purchase of Building & $(300,000)$ & $(300,000)$ \\
\hline Purchase of Equipment & $(40,000)$ & $(40,000)$ \\
\hline Cash Inflow (Outflow) from Investing Activities & $(390,000)$ & $(390,000)$ \\
\hline \multicolumn{3}{|l|}{ Cash Flows from Financing Activities: } \\
\hline Issuance of Stock & 500,000 & 500,000 \\
\hline Proceeds from Note Payable & 300,000 & 300,000 \\
\hline Payment on Note Payable & $(30,000)$ & $(30,000)$ \\
\hline Payment of Cash Dividends & $(25,000)$ & $(25,000)$ \\
\hline Payment on Finance Lease Liability & 0 & $(5,132)$ \\
\hline Cash Inflow (Outflow) from Financing Activities & 745,000 & 739,868 \\
\hline Net Change in Cash & $€ \overline{339,731}$ & $€ \overline{323,879}$ \\
\hline Beginning Cash Balance, January 1, 2014 & $\underline{0}$ & 0 \\
\hline Ending Cash Balance, December 31, 2014 & $\underline{\underline{339,731}}$ & $\underline{\underline{323,879}}$ \\
\hline
\end{tabular}

Table 11: Solution to Requirement 3 - Ratio Analysis

\begin{tabular}{|l|r|r|}
\hline & Munich Windet & AmsterWind \\
\hline Liquidity Ratios: & & \\
\hline Current ratio & 5.99 & 5.56 \\
\hline Acid-test ratio & 3.89 & 3.48 \\
\hline A/R Turnover & 5.26 & 5.05 \\
\hline Days to Collect Receivables & 69.39 & 72.28 \\
\hline Inventory Turnover & 2.40 & 2.20 \\
\hline Days to sell inventory & 152.08 & 165.91 \\
\hline Operating Cycle & 221.47 & 237.19 \\
\hline Profitability Ratios: & & \\
\hline Gross Profit Margin & $47.60 \%$ & $48.94 \%$ \\
\hline Profit Margin & $9.35 \%$ & $19.91 \%$ \\
\hline Return on Assets (ROA) & $4.70 \%$ & $9.20 \%$ \\
\hline Return on Equity (ROE) & $8.13 \%$ & $14.85 \%$ \\
\hline Earnings per Share & $€ 8.41$ & $€ 17.92$ \\
\hline Long-term Solvency Ratios: & & \\
\hline Debt Ratio & 0.42 & 0.38 \\
\hline Times Interest Earned & 8.25 & 7.13 \\
\hline
\end{tabular}

\section{Comparability}

The goal of this case is to help students see that while both companies report using IFRS, comparability remains a challenge. Comparability of financial statements and ratios between Munich Windet and AmsterWind are specifically affected by:

- $\quad$ Management estimates of useful life and salvage value on the building and equipment

- $\quad$ Management choice to apply revaluation accounting to the building 
- $\quad$ Management estimate for bad debt expense as a percentage of ending accounts receivable

- $\quad$ Management choice in inventory costing method used (FIFO or weighted average)

- Management judgment on how to record an equipment lease (financial or operating)

- Management judgment on whether a potential lawsuit is probable and therefore, should be recorded as a provision

This case can facilitate a discussion on comparability. For instance, what is comparability and how is it achieved? How do accounting choices, estimates, and judgment reduce comparability? If worldwide adoption of IFRS is achieved, will cross-country comparability improve? If all companies follow the same set of accounting standards, does that guarantee comparability? Comparability is one of the qualitative characteristics which accounting information should possess. Potential benefits of more comparable accounting information are a lower cost of capital and more efficient capital allocation. Accounting information is comparable when accounting standards and policies are applied consistently from one period to another, one company to another, and from one region to another. Companies have comparable reporting if, for a given set of economic events, these companies produce similar financial statements. There can be a lack of comparability if two different companies account for comparable economic transactions differently, depending on the opinion of each company and the professional judgment of their management in making accounting decisions. This in turn can defeat one of the major purposes of IFRS, which is to increase comparability across the globe.

IFRS gives companies substantial reporting discretion because the application of IFRS often involves considerable management judgment. Reporting discretion is given to managers for a good reason (Watts \& Zimmerman, 1986). Reporting discretion allows managers to use internal information to produce reports that more accurately reflect company performance and are most informative to external stakeholders. Conversely, reporting discretion allows for more managed earnings, underreported liabilities, or income smoothing, to name a few (Hail, Luez, \& Wysocki, 2010). Universal adoption of a single set of accounting standards (i.e., IFRS) is not enough to ensure comparable reporting and disclosure practices worldwide. Accounting decisions made by management will impact comparability and the financial results of a company. While comparability ideally will improve if all countries follow IFRS, a single set of accounting standards by itself does not guarantee comparability, neither within a country nor across countries. This applies to any set of accounting standards where judgment is allowed, not just IFRS. The same challenges exist when comparing US companies that follow US GAAP.

In this case, there are no operational differences between Munich Windet and AmsterWind. The differences in the financial results of these two companies are due entirely to accounting decisions. Students should begin to see and understand the differences between actual economic transactions and recorded transactions and that there is no such thing as the "true" income. Reported assets, liabilities, net incomes, and cash flow are very different even though the companies end the year with the same physical inventory, accounts receivable, and tangible assets and have the same future commitments for the next year. Thus, comparability is difficult. The same economic transactions have been accounted for differently due to management judgment and reporting discretion. AmsterWind profitability appears better on paper. AmsterWind's net income of $€ 89,614$ is more than double the net income of $€ 42,056$ for Munich Windet. AmsterWind's total assets are $€ 79,777$ higher than Munich Windet, equity is $€ 86,225$ higher, and liabilities are $€ 6,447$ lower even with the finance lease liability being recorded by AmsterWind. The difference in cash flows between the two companies of $€ 15,852$ is entirely due to the cash payment for taxes $(€ 29,871-€ 14,019)$, which is because of the difference in net income. Other than the cash payment for taxes, the companies are economically the exact same even though the financial statements look very different.

\section{The Impact of Culture on Accounting Decisions}

Can cultural differences between Germany and the Netherlands affect management judgment in making accounting decisions? What are the cultural differences between Germans and the Dutch? Is there any correlation between culture and accounting decisions made by management? Would you expect to find differences in financial results because of differences in culture? How does culture play a role in the comparability of financial information? This case gives instructors an opportunity to discuss culture and the potential impact on accounting decisions. The two companies in this case are located in Germany and the Netherlands. There are cultural 
differences between Germany and the Netherlands, which have the potential to influence how accountants in those countries interpret and apply accounting standards.

As a framework for understanding cultural differences, most research is based upon one of the largest crosscultural surveys ever conducted. Social psychology researcher Geert Hofstede (2001 \& 1980) collected data on cultural values from approximately 116,000 employees of a multinational company located in 50 countries and three regions around the world. He identified five cultural dimensions that reflect core values and help explain general similarities and differences in cultures. These dimensions are:

- Uncertainty avoidance (range from strong to weak) - how comfortable individuals in a society feel with uncertainty and ambiguity;

- Individualism (range from individualistic to collectivist) - a society's preference for a loosely knit social fabric or a more interdependent, tightly knit social fabric;

- $\quad$ Achievement orientation (range from long-term to short-term) - how much values such as performance and visible achievement are emphasized; and

- Power Distance (range from high to low) - how much hierarchy and unequal power distribution are accepted in a culture.

- $\quad$ Masculinity/Femininity (range from masculine to feminine) - how much society emphasizes traditional masculine values of performance and achievement rather than feminine values of relationships, caring, and nurturing.

Germany is considered a strong uncertainty avoidance country where there is a low tolerance for uncertainty and ambiguity. There are more rigid rules of behavior, laws are stricter, and penalties heavier. The Dutch also have preference for uncertainty avoidance, but not nearly as strong as Germany. The Dutch culture is considered a more individualistic society than Germany. Both cultures have more of a short-term versus long-term achievement orientation and rank moderately on the power distance dimension (Hofstede, 2001; Hofstede, 1980).

Accounting researchers have examined the link between Hoftstede's cultural values and a country's accounting values (Gray, 1988; Radebaugh \& Gray, 2001; Doupnik, 2008; Tsakumis, Campbell, \& Doupnik, 2009; Doupnik \& Richter, 2003). The two accounting values most correlated with culture are the accounting values of conservatism and secrecy. Conservatism is a preference for a cautious approach to income measurement and a tendency to defer the recognition of assets and items that increase net income. Similarly, the FASB describes conservatism as the choice of the lower estimate of future cash flows when two estimates are equally likely. Secrecy is a preference for confidentiality and the restriction of disclosure of information about the business only to those closely involved. Countries with strong uncertainty avoidance, lower individualism, and lower achievement orientation are most correlated with higher levels of conservatism and secrecy. Based on Hofstede's cultural dimensions rankings, research supports Germany as a country where higher levels of conservatism and secrecy are expected. The Dutch culture is associated with lower levels of conservatism and secrecy.

Culture is most likely to influence both the interpretation and the application of financial reporting standards where judgment is required. This may be especially of concern with IFRS since IFRS is considered more principles-based and often requires substantial judgment on the part of the accountant (Doupnik, 2008).

\section{Cultural Values $\rightarrow$ Accounting Values $\rightarrow$ Application of Financial Reporting Standards}

Munich Windet had a much more conservative measurement of net income at $€ 39,252$ compared to AmsterWind's net income of $€ 89,614$ (more than double). The more conservative measurement of net income for Munich Windet was due to the shorter useful live and higher salvage value on the building and equipment, a higher percent of estimated bad debt, a more conservative inventory costing method (weighted average compared to FIFO), recording an operating lease instead of finance lease on the equipment, and the decision to accrue for a potential loss related to the lawsuit. All of these decisions on the part of German management for Munich Windet are more conservative, which results in a significantly lower net income. This is consistent with what one might expect within the German culture. The Dutch management chose longer useful lives and lower salvage values, revaluation of PPE, a lower percentage of estimated bad debts, FIFO, the recognition of a finance lease, and a disclosure only 
approach to the potential lawsuit. These accounting decisions result in a much higher net income and higher total assets, also what one might expect within the Dutch culture.

\section{The Impact of the Accounting Environment on Accounting Decisions}

Another potential influence on accounting decisions and the application of IFRS, and thus comparability, are the accounting practices that were in place in a country before IFRS was adopted and the overall accounting environment within a country. The European Union required all countries to use IFRS beginning in 2005. Prior to this, countries followed their own country's GAAP. Prior to adoption of IFRS German accounting was known to have the following characteristics (Doupnik \& Perera, 2015; Choi \& Meek, 2011):

- German accounting was heavily influenced by tax law. There was no distinction between tax accounting and financial accounting.

- The primary source of finance for German companies were bank loans rather than equity raised through the capital market.

- $\quad$ Creditor protection was a fundamental concern of German accounting systems.

- Conservative balance sheet valuations were central to creditor protection (undervalue assets and overvalue liabilities).

Although German accounting has evolved greatly with the adoption of IFRS, the following characteristics are still associated with the German accounting environment:

- $\quad$ All German accounting rules are written into German law.

- Income amounts are measured conservatively. That leaves less that can be distributed in dividends to shareholders and provides more creditor protection. Lower net income also minimizes income taxes.

- $\quad$ Desired lower income is also influenced by the desire to mitigate labor unions' demands for higher wages and to report stable income over time.

- Germany is one of the world's staunchest adherents to the historical cost principle.

- $\quad$ Finance leases are often not capitalized.

- Provisions as estimates of future expenses or losses are used heavily. Provisions must be set up for deferred maintenance expense, product guarantees, potential losses from pending transactions, and other uncertain liabilities.

The accounting environment in the Netherlands currently and prior to IFRS adoption has the following characteristics (Doupnik \& Perera, 2015; Choi \& Meek, 2011):

- $\quad$ Relatively permissive statutory accounting and financial reporting requirements, but very high professional practice standards.

- $\quad$ Accounting is oriented towards fair presentation.

- $\quad$ The Dutch were one of the earliest proponents of IFRS.

- $\quad$ Netherlands is the home of many large multi-nationals.

- $\quad$ The Dutch flexibility toward accounting measurements is most evident in permitting the use of current values for tangible assets such as inventory and depreciable assets. The Dutch are known for their use of current value accounting. With the adoption of IFRS, current value accounting is not used in practice but current value information is still found in the footnotes.

- More opportunities for income smoothing might be expected because of flexibility in applying measurement rules.

Several of the accounting decisions in this case are consistent with what might be expected considering historical accounting practices in each country and the overall accounting environment. German measurement of income is conservative for creditor protection, finance leases are often not recorded, and provisions are used heavily. In the Netherlands, emphasis is placed on fair presentation (i.e., recognizing a finance lease) and heavy emphasis is placed on the shareholders' perspective. 


\section{Ratio Analysis}

This case also highlights the impact of accounting decisions on financial ratios used to assess a company's performance. Munich Windet has a higher current ratio and acid test ratio than AmsterWind, which implies they are in better position to pay short-term liabilities. However, other than the cash payment for taxes, both companies have the same cash on hand, inventory on hand, and accounts receivable due from customers. They also have the same short-term obligations due next year. The inventory costing method and the estimate for bad debts are the reason for the difference in current assets. The difference in current liabilities is due to the recognition of the current portion of the lease payment due in 2015 as a current liability, although both companies have a $€ 10,000$ lease obligation in the next year.

Liquidity Ratios: Munich Windet has a higher accounts receivable turnover ratio and takes three fewer days to collect receivables. However, both companies had the same credit sales and collected the same amount of cash for receivables. The lower accounts receivable for Munich Windet is due to the management estimates for bad debts and the allowance for uncollectible accounts, which gives the appearance of a higher receivable turnover and lower collection cycle. Munich Windet also has a higher inventory turnover ratio and appears to take 14 fewer days to sell inventory. These results are due entirely to the use of different inventory costing methods since inventory purchased and inventory sold for both companies are the exact same. Finally, Munich Windet appears to have a shorter operating cycle, but that is because of the fewer days to collect receivables and sell inventory and the reasons already mentioned.

Profitability and Solvency Ratios: In analyzing the profitability and solvency ratios, AmsterWind appears on paper to be more profitable and more solvent. AmsterWind has a higher gross profit margin of $48.94 \%$ compared to $47.60 \%$ for Munich Windet. This is because of the difference in cost of goods sold as a result of using FIFO compared to weighted average to account for inventory. The profit margin ratio for AmsterWind is $19.91 \%$ compared to $9.35 \%$ for Munich Windet. This difference is due to the difference in net income because of the accounting decisions already discussed. AmsterWind's higher return on assets, return on equity, and earnings per share are also a result of different net incomes, assets, and liabilities reported by the two companies. AmsterWind has a lower debt ratio and times interest earned ratio, also due to accounting decisions.

\section{CONCLUSION}

Proponents argue worldwide adoption of IFRS would greatly improve comparability of financial information across borders. While this is partly true, accounting decisions and diversity in the application of IFRS will always present challenges to the comparability of financial statements across countries and industries. Similar to US GAAP, IFRS allows management the flexibility to make many accounting decisions that influence financial performance and results. When borders are crossed, these accounting decisions, and thus comparability, can also be impacted by such things as culture and differences in the accounting environment in different countries.

\section{AUTHOR INFORMATION}

Kris Portz is a professor of accounting at St. Cloud State University. She holds a PhD in accounting from the University of Nebraska - Lincoln and teaches courses in intermediate accounting and international accounting. Her research interests are in managerial accounting, international accounting, and accounting education. Her research has appeared in American Journal of Business, Journal of International Business Discipline, CMA Management Journal, and The Review of Business Information Systems. E-mail: ksportz@stcloudstate.edu (Corresponding author)

Joel Strong is a professor of accounting at St. Cloud State University. He holds a PhD in accounting from the University of Nebraska - Lincoln and teaches courses in intermediate accounting and auditing. His research interests are in behavioral accounting and accounting education. His research has appeared in Advances in Accounting, Research in Governmental and Nonprofit Accounting, The Accounting Educators' Journal, and The Review of Business Information Systems. E-mail: jmstrong@ stcloudstate.edu 


\section{REFERENCES}

1. Choi, F., \& Meek, G. (2011). International accounting (7th ed.). Upper Saddle River, NJ: Pearson.

2. Doupnik, T. (2008). Influence of Culture on earnings mangement: A note. Abacus, 44(3), 317-340.

3. Doupnik, T., \& Perera, H. (2015). International accounting (4th ed.). New York: McGraw-Hill Education.

4. Doupnik, T., \& Richter, M. (2003). Interpretation of uncertainty expressions: A cross-national study. Accounting, Organizations and Society, 28(1), 15-35.

5. Gray, S. (1988). Towards a theory of cultural influence on the development of accounting systems internationally. Abacus, 24(1), 1-15.

6. Hail, L., Luez, C., \& Wysocki, P. (2010). Global accounting convergence and the potential adoption of IFRS by the U.S. (Part 1): Conceptual underpinnings and economic analysis. Accounting Horizons, 24(3), 355-394.

7. Hofstede, G. (2001). Culture's consequences: Comparing values, behaviors, institutions, and organizations across nations (2nd ed.). Thousand Oaks, CA: Sage.

8. Hofstede, G. (1980). Culture's consequences: International differences in work-related values. London: Sage.

9. Radebaugh, L., \& Gray, S. (2001). International accounting and multinational enterprises (5th ed.). New York, NY: Wiley.

10. Tsakumis, G., Campell Sr., D., \& Doupnik, T. (2009). IFRS: Beyond the standards. Journal of Accountancy, 207(2), 34-39.

11. Watts, R., \& Zimmerman, J. (1986). Positive accounting theory. London: Prentice Hall. 


\section{APPENDIX 1}

\section{Formulas for Financial Ratios}

\begin{tabular}{|c|c|c|}
\hline \multicolumn{3}{|c|}{ LIQUIDITY RATIOS } \\
\hline Current Ratio & $\begin{array}{l}\text { Measures ability to pay current liabilities with } \\
\text { current assets }\end{array}$ & $\begin{array}{c}\text { Current assets } \\
\text { Current liabilities }\end{array}$ \\
\hline Acid-test (quick) ratio & Measures immediate short-term liquidity & $\begin{array}{l}\text { Cash + short-term investments + net } \\
\frac{\text { receivables }}{\text { Current liabilities }}\end{array}$ \\
\hline $\begin{array}{l}\text { Accounts receivable } \\
\text { turnover }\end{array}$ & $\begin{array}{l}\text { Calculates number of times in an operating cycle a } \\
\text { company collects its receivable balance }\end{array}$ & $\frac{\text { Net credit sales }}{\text { Average net accounts receivable }}$ \\
\hline $\begin{array}{l}\text { Days to collect } \\
\text { receivables }\end{array}$ & $\begin{array}{l}\text { Calculates the number of days it takes to collect the } \\
\text { average accounts receivable balance }\end{array}$ & $\frac{365 \text { days }}{\text { Accounts receivable turnover }}$ \\
\hline Inventory turnover & $\begin{array}{l}\text { Calculates number of times the company sells their } \\
\text { inventory during a period }\end{array}$ & $\begin{array}{l}\text { Cost of goods sold } \\
\text { Average inventory }\end{array}$ \\
\hline Days to sell inventory & $\begin{array}{l}\text { Calculates the average number of days it takes to sell } \\
\text { the inventory }\end{array}$ & $\begin{array}{c}365 \text { days } \\
\text { Inventory turnover }\end{array}$ \\
\hline Operating cycle & $\begin{array}{l}\text { Measures the average number of days between the } \\
\text { purchase of inventory and the collection of cash } \\
\text { from the sale of inventory }\end{array}$ & $\begin{array}{c}\text { Days to sell inventory + days to collect } \\
\text { receivables }\end{array}$ \\
\hline
\end{tabular}

\begin{tabular}{|c|c|c|}
\hline \multicolumn{3}{|c|}{ PROFITABILITY RATIOS } \\
\hline Gross profit margin & Measures gross profit as a percentage of sales & $\frac{\text { Sales }- \text { cost of goods sold }}{\text { Sales }}$ \\
\hline Profit margin & $\begin{array}{l}\text { Measures the company's ability to turn its sales into } \\
\text { net income }\end{array}$ & $\begin{array}{c}\text { Net income } \\
\text { Sales }\end{array}$ \\
\hline $\begin{array}{l}\text { Return on Assets } \\
\text { (ROA) }\end{array}$ & $\begin{array}{l}\text { Measures how much net income is generated for } \\
\text { each } \$ 1 \text { of assets the company has }\end{array}$ & $\begin{array}{c}\text { Net income } \\
\text { Average total assets }\end{array}$ \\
\hline $\begin{array}{l}\text { Return on owners' } \\
\text { equity (ROE) }\end{array}$ & $\begin{array}{l}\text { Measures how much net income is generated for } \\
\text { each } \$ 1 \text { of common stockholders' equity }\end{array}$ & $\begin{array}{l}\text { Net income - preferred dividends } \\
\text { Average common stockholders' equity }\end{array}$ \\
\hline Earnings per share & $\begin{array}{l}\text { Measures the net income earned for each share of } \\
\text { outstanding common stock }\end{array}$ & $\begin{array}{c}\text { Net income - preferred dividends } \\
\text { Average number of common shares } \\
\text { outstanding for the year }\end{array}$ \\
\hline
\end{tabular}

\section{SOLVENCY RATIOS}

\begin{tabular}{|l|l|c|}
\hline \multicolumn{2}{|c|}{ SOLVENCY RATIOS } & Total liabilities \\
\hline Debt ratio & $\begin{array}{l}\text { Measures the portion of investment that is from debt; } \\
\text { indicates leverage and borrowing power }\end{array}$ \\
\hline Times interest earned & $\begin{array}{l}\text { Indicates the ability of the company to pay interest } \\
\text { as it comes due }\end{array}$ & $\frac{\text { Income from operations }}{\text { Interest expense }}$ \\
\hline
\end{tabular}

